\title{
Lactic acid bacteria stress response to preservation processes in the beverage and juice industry
}

\author{
Joanna Bucka-Kolendo ${ }^{凶}$ and Barbara Sokołowska \\ Department of Fruit and Vegetable Products Technology, prof. Wacław Dąbrowski Institute of Agricultural and Food Biotechnology, \\ Warsaw, Poland
}

In this review we summarize stress factors that affect the lactic acid bacteria (LAB) and cause different molecular stress responses. LAB belong to a group of bacteria that is very widespread in food and beverages. They are present, and desired, in fermented products like yogurts, cheese, vegetables, meat or wine. In most of them, LAB are providing positive sensory and nutritive features. However, as harmless and desired microbes in one product, LAB can cause spoilage and a bad taste of others, especially in juices and beverages. LAB are resistant to many stress factors which allows them to survive in harsh environments. The most common stress factors they have to deal with are: heat, cold, acidity, $\mathrm{NaCl}$ and high hydrostatic pressure (HHP). Their ability to survive depends on their skills to cope with stress factors. Under stress conditions, LAB activate mechanisms that allow them to adjust to the new conditions, which can influence their viability and technological properties. This ability to adapt to different stress conditions may come from the cross-protection systems they have, as resistance to one factor may help them to deal with the other stress effectors. LAB are highly valuable for the food industry and that is why it is important to understand their stress response mechanisms.

Key words: Lactic acid bacteria, LAB, stress factors, stress response, cross-protection

Received: 05 January, 2017; revised: 12 April, 2017; accepted:

12 April, 2017; available on-line: 09 August, 2017

e-mail: joanna.bucka@ibprs.pl

Abbreviations: HHP, high hydrostatic pressure; LAB, lactic acid bacteria

\section{INTRODUCTION}

Lactic Acid Bacteria (LAB) are the most widespread group of bacteria that is used in fermented foods. They are natural inhabitants of the human gastric intestine, and can be applied in different fermented products and probiotic foods (Ficco et al., 2009). They are present in products like yogurts, sourdoughs, sour vegetables, cheese, wine or meat and play a crucial role in the development of the organoleptic and hygienic quality of fermented products (van de Gutche et al., 2002). The technological benefit of Lactic Acid Bacteria depends on the ability to enhance safety, flavour, texture and nutritional value (Salminen \& von Wright, 2004). Some LAB, due to their probiotic properties, can be used in the production of functional food and potential oral vaccines (Shah 2007; Siragusa et al., 2007; Parente et al., 2010).

At the same time, LAB can cause spoilage of food. They can grow in improperly pasteurized beverages and juices in bottles and cans, in vacuum packed products with a deficit of oxygen. LAB can enter a given product along with the raw material, additives or with packing materials (Lawlor et al., 2009). The most common species that cause spoilage of beverages are Lactobacillus paracasei and Leuconostoc mesenteroides (Back, 2005), as well as Lactobacillus brevis, Lactobacillus buchneri, Lactobacillus plantarum, Lactobacillus perolens and Weissella confusa. Many bacteria from these species are also responsible for beer spoilage.

LAB mainly ferment sucrose to lactic acid. Depending on the species and growth conditions, catabolism of sugars can also lead to the formation of ethanol, acetate, formic acid or succinate (Hammes \& Hertel, 2009). Some of the bacteria can produce diacetyl that gives a bitter taste and flavour of the products. That is why $\mathrm{LAB}$ are undesirable in beverages and juices. It has been reported that formic acid in apple juices can indicate food spoilage (Gökmen \& Acar, 2004). The L. mesenteroides and $W$. confusa bacteria can synthesize compounds which cause ropiness of the final product (Back, 2005). Ropiness caused by LAB is the reason why these bacteria are believed to be potentially a cider spoilage indicator (Ibarburu et al., 2010).

In alcohol beverages, LAB can influence the bitter flavor by converting glycerol to 3-hydroxypropionaldehyde, which can transform to acrolein and bind with polyphenols creating bitter compounds (Sauvageot et al., 2000; Garai-Ibabe et al., 2008; Juvonen et al., 2011).

\section{PRESERVATION METHODS}

Many factors affecting bacteria during the preservation process of beverages and juices can act as potential stress effectors for them. Physical preservation techniques of food are used in order to reduce the number, or to prevent the growth of unwanted microflora in the products (Juvonen et al., 2011). Traditional prevention techniques used in the beverage industry include thermal processing and filtration. Thermal processing is the most efficient technique of food preservation. It can prevent not only the growth of unwanted microflora but also can suppress unwanted enzymatic activity (Back 2005). However, processes that use high temperatures destroy many bioactive and aromatic compounds, causing modification of the flavor, color and nutritional value. The increase of consumer demands for "fresh like" foods brings new challenges for techniques used in food preservation. Nowadays, high hydrostatic pressure techniques (HHP) are used more often, as they can reduce the number of microbes in liquid food products like beverages, juices and alcohol beverages - beer, wine or cider. 
High hydrostatic pressure can induce in bacteria many changes, like physiological changes (Wouters et al., 1998; Korakli et al., 2002), changes in gene expression (Welch et al., 1993; Drews et al., 2002; Wemekamp-Kamphuis et al., 2002) and in protein translation (Sato et al., 1995; Ehrmann et al., 2001), and can also lead to cell damage (Ulmer et al., 2002) and death (Vogel et al., 2002; Scheyhing et al., 2004). HHP does not break the covalent bindings. Thanks to this, the primary structure of proteins and fatty acids stays unaffected (Considine et al., 2008; Reundueles et al., 2011). Molecules, like vitamins, amino acids, flavor compounds and other small molecules stay undamaged by HHP, as well as organoleptic characteristics of food. Serrazanetti and coworkers (2009 and 2013) had shown that some proteins undergo induction as a result of HHP, and a few of them are also involved in different types of stress responses including cross-protection.

Stress response to HHP cannot be expected in LAB while it is perfomred in their natural environment, as those bacteria are not normally exposed to this stress factor (Lorca \& Font de Valdez, 2009). Compared to other stress factors, LAB response to HHP is more complex, as some of the effects are very similar to those caused by other factors. Their ability to react to HHP can be explained by a bacteria cross-protection system to different stress factors (Scheyhing et al., 2004; Lorca \& Font de Valdez, 2009). However, the LAB cross-protection response to HHP is not well documented in the literature as yet. In Lactobacillus plantarum, higher sensitivity to HHP was observed when heat shock was used at the same time as HHP.

As shown by Sokołowska and coworkers (2012 and 2014), LAB belong to a group of organisms that are resistant to the effect of high hydrostatic pressure, and their growth can be a valuable tool to evaluate the shelf life of preserved products with this method (Mathias et al., 2013).

\section{LAB STRESS RESPONSE MECHANISMS}

It is believed that environmental stress response in LAB can vary between species and depends on the type of stress that has been applied (van de Gutche et al., 2002). The well- known LAB stress responses are those to heat shock (De Angelis et al., 2004), bile (Bron et al., 2006), and oxidative (Serrano et al., 2007), low pH and ethanol stresses (Alegría et al., 2004; Parente et al., 2010).

Bacterial stress response is based on coordinated genes expression that affects different cellular processes (cell division, transport, cell membrane composition, DNA metabolism) (Stortz \& Hengge-Aronis, 2000; van de Gutche et al., 2002). LAB achieve an integrated stress response through a regulatory web that allows them to react to environmental changes. Bacteria activate mechanisms allowing them to adapt to new conditions, which can influence the viability and technological properties. Adaptation to stress conditions can also cause morphological changes which affect food spoilage (Asano et al., 2007). Many typical spoilages that occur in beverages, juices and alcohol beverages, like ropiness and volatile phenols formation, are related to stress. LAB have a significance in the food industry and that is why knowing their stress effectors is very important (van de Guchte et al., 2002; Parente et al., 2010). Under stress conditions, in order to protect cells from influence of the same or other type of stress factors, bacteria can trigger a cross-protection response (van de Guchte et al., 2002; Smits \& Brul, 2005; Chung et al., 2006).

\section{GENE REGULATION IN THE LAB STRESS RESPONSE}

In an unfavourable environment, many forms of LAB can convert into VBNC - a viable but nonculturable state. In this state, the bacteria cannot be identified with classical microbiology methods, and this can be achieved only with the use of more advanced molecular biology techniques. Considering niche differentiation that LAB are able to colonize, a high phenotype and genotype diversity is observed (Molenaar et al., 2005; Di Cagno et al., 2010; Siezen et al., 2010; Ricciardi et al., 2012). Gene expression caused by different stress factors allows to identify biomarkers responsible for stress resistance (Juvonen et al., 2011).

Depending on the type of regulation, these genes are divided into six classes (Helman et al., 2001; Darmon et al., 2002; Schumann, 2003; Castaldo et al., 2006).

Class I and III are controlled by two types of transcriptional repressors: $\mathrm{HrcA}$ and CtsR. The first class is comprised by heat shock genes, including the dnaK and groEL operons. They encode proteins belonging to two chaperon complexes, DnaK-GrpE-DnaJ and GroES-GroEL, respectively (Castaldo et al., 2006). Both operons are regulated by the HrcA repressor protein, which binds with the CIRCE operator (Controlling Inverted Repeat for Chaperon Expression) under the stress-free conditions. Genes encoding heat shock proteins and HrcA are being used for taxonomical purposes of several species, including Lactobacillus (Blaiotta et al., 2008; Fiocco et al., 2010; Huang et al., 2010; Guidone et al., 2015).

The class II gene expression is dependent on the $\sigma \mathrm{B}$ sigma factor, the synthesis and activity of which is increased under different stresses (Hecker et al., 1996; Kruger \& Hecker, 1998; Varmanen et al., 2000).

Mechanisms of class IV transcriptional activation are not very well documented, while class $\mathrm{V}$ genes undergo regulation by a two-component signal transduction system (2CSs); for class VI, the regulation is still unknown (Schumann, 2003).

Initially, mechanism of the $\mathrm{LAB}$ response to stress conditions was compared with that of the documented model species $-B$. subtilis and E. coli. The best known stress response mechanisms are those present in the $B a$ cillus subtilis species, where, at high temperatures over 200 genes are expressed (as shown by Castaldo et al., 2006). However, it had turned out that there were some differences in these mechanisms. As Ricciardi and coworkers had shown, the Class I and Class III genes' stress response regulation differs in Lactobacillus plantarum from Bacillus subtilis, a model organism of Gram-positive bacteria. Other data suggest that stress response factors, like sigma factors, that are responsible for stress response in many Gram-positive and Gram-negative bacteria, are not important for LAB. The most striking difference is the lack of the $\sigma^{\beta}$ sigma factor, while several stress proteins, like DnaK, GroEL, Clp etc., and their regulators HrcA and CtsR are conserved.

The LAB stress response is regulated by a one-component regulatory system. For the Class I genes, major complexes of chaperons, like GroES-GroEL and GroEDnaK-DnaJ (Lorca \& Font de Valdez, 2009), are induced. Induction of these genes correlates with acid, ethanol, cold, osmotic, starvation and temperature stresses. In some bacteria, regulation of the GroES-GroEL and GroE-DnaK-DnaJ complexes, requires the presence of a $\sigma^{A}$ sigma factor promoter and a highly conserved inverted repeat CIRCE, which binds the $\operatorname{HrcA}$ repressor (Zuber and Schumann 1994). 
Table1. Response mechanisms of LAB to various stress conditions encountered during food processing and the major stress proteins or enzymes involved in the response (adapted from Ananta \& Knorr, 2004, Pavlovic et al., 2005; Jofre et al., 2007; Franz \& Holzapfel, 2011; Mota et al., 2013)

\begin{tabular}{|c|c|c|c|}
\hline Stress response & $\begin{array}{l}\text { Reported cross- } \\
\text {-resistance }\end{array}$ & Stress related resistance mechanism & Stress-related proteins/enzymes involved \\
\hline $\begin{array}{l}\text { Acid stress response } \\
\text { Two general types: } \\
\text { During log growth phase } \\
\text { (L-ATR; induced by nonle- } \\
\text { thal low pH) } \\
\text { In stationary phase, induc- } \\
\text { tion of } \\
\text { general stress response }\end{array}$ & $\begin{array}{l}\text { Heat, osmotic, } \\
\text { oxidative } \\
\text { (varies between } \\
\text { species) }\end{array}$ & $\begin{array}{l}\text { ATP-dependent expulsion of proteins } \\
\text { by protein pump } \\
\text { Activation of arginine deiminase } \\
\text { pathway-production of basic compo- } \\
\text { unds (e.g. ammonia) } \\
\text { Amino acid decarboxylation reac- } \\
\text { tions \& electrogenic transport } \\
\text { Change in cell envelope composition } \\
\text { of damaged proteins, DNA \& cell } \\
\text { components } \\
\text { Incremental expression of regula- } \\
\text { tors that promote minor or global } \\
\text { responses } \\
\text { Induction of heat shock proteins }\end{array}$ & $\begin{array}{l}\mathrm{F}_{0} \mathrm{~F}_{1}-\mathrm{ATPase} \\
\mathrm{K}^{+}-\mathrm{ATP} \text { ase } \\
\text { Arginine deiminase } \\
\text { Urease } \\
\text { Ornithine/arginine/lysine decarboxylase } \\
\text { Lo18 } \\
\text { Ffh } \\
\text { Heat shock chaperones \& regulators } \\
\text { (DnaK, GroEl, HrcA, CtsR) } \\
\text { recA, AP endonuclease, UvrSystem }\end{array}$ \\
\hline Oxidative stress response & $\begin{array}{l}\text { Heat, acid, general } \\
\text { stress resistance }\end{array}$ & $\begin{array}{l}\text { Reducing intracellular environment } \\
\text { Prevention of reactive oxygen spe- } \\
\text { cies formation } \\
\text { Target protection } \\
\text { Repair of oxidative damage }\end{array}$ & $\begin{array}{l}\text { Glutathione peroxidase, glutathione re- } \\
\text { ductase } \\
\text { Thioredoxin, thioredoxin reductase } \\
\text { NADH oxidase } \\
\text { Catalase } \\
\text { Pseudocatalase } \\
\text { Superoxide dismutase } \\
\text { Methionine sulfoxide reductase } \\
\text { Mannose phosphotransferase system } \\
\text { FLP (FNR-like protein) } \\
\text { RecA } \\
\text { Phosphate ABC transporter }\end{array}$ \\
\hline $\begin{array}{l}\text { Cold stress response } \\
\text { Transient adaptive } \\
\text { response i.e. cold } \\
\text { shock response }\end{array}$ & $\begin{array}{l}\text { Heat shock, fre- } \\
\text { ezing (cryotole- } \\
\text { rance) }\end{array}$ & $\begin{array}{l}\text { Production of cold-induced proteins } \\
\text { (CIPs) to maintain membrane fluidity } \\
\text { DNA supercoiling } \\
\text { Transcriptional \& translation }\end{array}$ & $\begin{array}{l}\text { CIPs involved in } \\
\text { Sugar metabolism (Hpr, CcpA, } \beta \text {-PGM, } \\
\beta \text {-phosphoglucomutase) } \\
\text { Chromosome structuring (HsIA) } \\
\text { Signal transduction (LIrC) } \\
\text { Stress adaptation (OsmC) } \\
\text { Proteolysis of misfolded proteins (ClpX } \\
\text { ATPase) } \\
\text { Cold shock protein (CSPs) } \\
\text { CspA-CspG, vary in number according to } \\
\text { species }\end{array}$ \\
\hline Osmotic stress response & Heat shock & $\begin{array}{l}\text { Exchange of compatible solutes to } \\
\text { maintain osmotic balance }\end{array}$ & $\begin{array}{l}\text { ATP-dependent uptakte system (QacT) } \\
\text { or ABC transporter (OpuA or BusA) (spe- } \\
\text { cies-dependent) for uptake of glycine- } \\
\text {-betaine, carnitine and proline during } \\
\text { hyperosmotic stress conditions, efflux by } \\
\text { unidentified channel protein } \\
\text { General stress proteins (GroEL, GroES, } \\
\text { DnaK) } \\
\text { Proteases FtsH, HtrA }\end{array}$ \\
\hline Heat shock response & $\begin{array}{l}\text { Acid, oxidative, } \\
\text { cold, osmotic, } \\
\text { alcohol }\end{array}$ & $\begin{array}{l}\text { Production of heat-inducible chape- } \\
\text { rones } \\
\text { Production of heat-inducible pro- } \\
\text { teases } \\
\text { Production of heat shock proteins }\end{array}$ & $\begin{array}{l}\text { Chaperon complex DnaK-GrpE-DnaJ \& } \\
\text { GroES-GroEL } \\
\text { HtrA/DegP protease, FtsH/HflB protease, } \\
\text { Clp protease (ClpB,C,E,P,Q,X \& Y), Lon } \\
\text { protease } \\
\text { Trigger factor, HrcA, HSP10, HSP23 (ClpP), } \\
\text { HSP26, HSP33, HSP40, DnaK/HSP70, Gro- } \\
\text { EL/HSP60, HSP84, HSP85, HSP100 } \\
\text { Small heat shock proteins (sHSPs), e.g. } \\
\text { Lo18, HSP18.5, HSP18.55, HSP19.3, } \\
\text { HSP16.4, HSP20 }\end{array}$ \\
\hline Bile stress response & Heat & $\begin{array}{l}\text { Metabolism of bile salts } \\
\text { Adaptation to bile stress } \\
\text { MDR efflux }\end{array}$ & $\begin{array}{l}\text { Bile salt hydrolase }(\mathrm{BSH}) \\
\text { DnaK, GroEL } \\
\text { MDR transporters }\end{array}$ \\
\hline $\begin{array}{l}\text { Nutrition starvation stress } \\
\text { response }\end{array}$ & $\begin{array}{l}\text { Heat, oxidative, } \\
\text { ethanol, acid, } \\
\text { osmotic }\end{array}$ & $\begin{array}{l}\text { Modification of cell morphology } \\
\text { Regulation of metabolism } \\
\text { Amino acid (arginine) catabolism }\end{array}$ & $\begin{array}{l}\text { General stress proteins } \\
\text { Proteins involved in carbon metabolism } \\
\text { (triose phosphate isomerase, putative } \\
\text { dihydroxy-acetone kinase, Gls } 24 \text { protein) } \\
\text { Proteins involved in amino acid catabo- } \\
\text { lism (carbomate kinase, putative glycine } \\
\text { cleavage system, L-serine dehydrogenase) }\end{array}$ \\
\hline
\end{tabular}




Ethanol stress response Heat, acid $\quad$ Production of heat shock proteins $\quad$ SHSPS, HSP18

\begin{tabular}{|c|c|c|c|}
\hline $\begin{array}{l}\text { High pressure stress re- } \\
\text { sponse }\end{array}$ & Heat, cold & $\begin{array}{l}\text { Biosynthesis of proteins preventing } \\
\text { thermal degradation } \\
\text { Expression of ribosomal protein } \\
\text { genes } \\
\text { Synthesis of translation factors } \\
\text { Transcription factors } \\
\text { Protein folding and stabilization } \\
\text { Energy metabolism-glycolysis } \\
\text { Cellular processes- adaptation to } \\
\text { atypical conditions } \\
\text { Nucleotide and nucleoside interco- } \\
\text { nversion } \\
\text { DNA replication, recombination and } \\
\text { repair }\end{array}$ & $\begin{array}{l}\text { Chaperones \& ATP-dependent protease } \\
\text { Translation factors (EF-G, EF-TU), genes } \\
\text { changing translation or chaperones (Gro- } \\
\text { EL, ClpL) } \\
\text { Proteins HSP60, gryA } \\
\text { Ribosome recyclingfactor (Rrf)Lsa1262 } \\
\text { Transcription antitermination protein } \\
\text { (NusG) Lsa1674 } \\
\text { DnaK chaperone protein (DnaK) Lsa1236 } \\
\text { Glyceraldehyde 3-P-dehydogenase (Gap) } \\
\text { General stress protein Lsa0169 } \\
\text { General stress protein Lsa0170 } \\
\text { Universal stress protein (Usp6) Lsa0836 } \\
\text { Universal stress protein (Usp5)Lsa0038 } \\
\text { Cold shock protein A family (Csp1) Lsa } \\
\text { 0768 } \\
\text { Adenylate kinase; } \\
\text { Ec } 2.7 .4 .3 \text { (Adk) } \\
\text { Lsa1744 } \\
\text { Single-standed DNA binding protein (Ssb) } \\
\text { Lsa0008 }\end{array}$ \\
\hline
\end{tabular}

Regulation of heat stress response genes in Gram-positive bacteria was described as HrcA or CtsR dependent. This statement is still valid for B. subtilis and closely related to them Clostridum perfingens or Listeria monocytogenes bacteria (Chastanet et al., 2003, Chastanet and Msadek 2003, Lorca and Font de Valdez 2009).

The Class III heat shock genes CtsR repressor binds directly to a specific repeat sequence (the CtsR Box: a/ggtcaaaNaNa/ggtcaaa)(Derre et al., 2000). This sequence was found in other Gram-positive bacteria, like: Listeria monocytogenes, Streptococcus salivarius, Streptococcus pneumonia, Streptococcus pyogenes, Streptococcus thermophilus, Enterococcus faecalis, Staphylococcus aureus, Lenconostoc oenos, Lactobacillus sake, Lactobacillus lactis, and Clostridium acetobutylicum (Smeds et al., 1998, Derre et al., 1999, Ingmer et al., 1999).

In Lactobacillus plantarum, CtsR regulates transcription of the ctsR-clpC operon, hsp1 and ftsH (Russo et al., 2012). Deletion of CtsR influences the temperature sensitivity and changes morphology of cells under stress. It suggests that in L. plantarum, CtsR has a significant role in the heat shock tolerance by controlling the processes of protein quality (Fiocco et al., 2009, Fiocco et al., 2010). CtsR gene homologs were also identified in other bacteria: Listeria, Streptococcus, Leuconostoc, Lactococcus or Clostridium, which indicates that heat shock gene regulation by CtsR is highly conserved in those bacteria. That allows us to state that heat shock response regulation by CtsR is highly conserved in the Gram-positive bacteria (Derre et al., 1999).

Stress response to HPP has been well studied in the L. sakei and L. sanfranciscensis strains (Hörmann et al., 2006; Jofré et al., 2007). Hörmann et al.,(2006) had observed changes in the expression of 16 genes in Lactobacillus sanfranciscensis as an effect of HPP. Nine of those genes were over-expressed and seven were silenced as a result of stress. That can suggest that in LAB the stress response to HPP is negatively regulated by a one component protein system HrcA or CtsR, and by a two-component system of signal transduction (2CSs).
An overview of different types of the LAB stresses, their reported cross-resistance and the resistance mechanisms are shown in Table 1.

\section{CONCLUSION}

Growing pressure to lower the use of thermal processes and chemical preservatives in beverages and juices leads to maintain more natural products. However, this process may cause higher contamination by unwanted compounds produced by LAB. Although they may be harmless and desired microbes in one product, LAB can cause spoilage of other products.

A comparative study of the response of different bacterial strains to the same stress factors shows their diverse characteristics. In the context of food protection treatment, it is important to take under consideration that even closely related organisms can posses their individual, specific stress response mechanisms.

That is why, for different bacterial strains, there is a cross-response to various stress factors and cross-protection to different food preservation systems, like HHP, acidic, cold, and salt treatment, which needs to be taken under consideration.

Therefore the identification of stress response regulatory genes, like HrcA, CtsR, DnaK and FtsH, is necessary to control and evaluate the relationship between polymorphism of LAB in food products and the ability to cope with stress. At the same time, as a consequence of a highly conserved status in bacteria, these genes can be use as biomarkers.

Although present molecular methods allow to better understand the LAB taxonomy, it is believed that more data is needed to understand the stress related physiological dependence of those bacteria (De Angelis \& Gobetti, 2011).

Genetic diversity evaluation of lactic acid bacteria, as an effect of stress factors that can occur during beverage and juice preservation processes, is important to control $\mathrm{LAB}$ in those products. A better understanding of the stress response related mechanisms in LAB allows to understand the basis of adaptation response and cross- 
protection mechanism they undergo (Van de Guchte et al., 2002), and thus can make these bacteria more useful in industrial processes.

\section{REFERENCES}

Alegría EG, López I, Ruiz JI, Saenz J, Fernández E, Zarazaga M, Dizy M, Torres C, Ruiz-Larrea F (2004) High tolerance of wild Lactobacillus plantarum and Oenococcus oeni strains to lyophilisation and stress environmental conditions of acid $\mathrm{pH}$ and ethanol. FEMS Microbiol Lett 230: 53-61. doi: 10.1016/S0378-1097(03)00854-1

Ananta E, Knorr D (2004) Evidence on the role of protein biosynthesis in the induction of heat tolerance of Lactobacillus rbamnosus GG by pressure pre-treatment. Int J Food Microbiol 96: 307-313. doi: 10.1016/j.ijfoodmicro.2004.04.012

Asano S, Suzuki K, Iijima K, Motoyama H, Kurivama H, Kitagawa Y (2007) Effect of morphological changes in beer-spoilage lactic acid bacteria on membrane filtration in breweries. J Biosci Bioengin 104: 334-338. doi: 10.1263/jbb.104.334

Back W (2005) Colour Atlas and Handbook of Beverage Biology. Back ed. pp 317. Verlag Hans Carl: Nürnberg, Germany

Blaiotta G, Fusco V, Ercolini D, Aponte M, Pepe O, Villani F (2008) Lactobacillus strain diversity based on partial hsp60 gene sequences and design of PCR restriction fragment length polymorphism assays for species identification and differentiation. Appl Environ Microbiol 74: 208-215. doi: 10.1128/AEM.01711-07

Bron PA, Molenaar D, de Vos WM, Kleerebezem M (2006) DNA micro-array-based identification of bile-responsive genes in Lactobacillus plantarum. J Appl Microbiol 100: 728-738. http://dx.doi.org/10.4161/ bbug 2.2.13910

Castaldo C, Siciliano RA, Muscariello L, Marasco R, Sacco M (2006) CcpA affects expression of the groESL and dnaK operons in Lac tobacillus plantarum. Microbial Cell Factories 5: 35. doi: 10.1186/14752859-5-35

Chastnet A, Fert J, Msadek T (2003) Comparative genomic reveal novel heat shock regulatory mechanisms in Staphylococcus aureus and other Gram-positive bacteria. Mol Microbiol 47: 1061-1073. doi: 10.1046/j.1365-2958.2003.03355.x

Chastnet A, Msadek T (2003) ClpP of Sreptococcus salivarius is a novel member of the dually regulated class of stress response genes in gram-positive bacteria. J Bacteriol 185: 683-687. doi: 10.1128/ JB.185.2.683-687.2003

Chung HJ, Bang W, Drake M (2006) Stress response of Escherichia coli. Comp Rev Food Sci Food Safety 5: 52-64. doi: 10.1111/j.15414337.2006.00002.x

Considine KM, Kelly AL, Fitzgerald GF, Hill C, Sleator RD (2008) High-pressure processing effects on microbial food safety and food quality. Microbiol Lett 281: 1-9. doi: 10.1111/j.15746968.2008.01084.x

Darmon E, Noone D, Masson A, Bron S, Kuipers OP, Devine KM, van Dijl JM (2002) A novel class of heat and secretion stress-responsive genes is controlled by the autoregulated CssRS two-component system of Bacillus subtilis. I Bacteriol 184: 5661-5671. doi: 10.1128/JB.184.20.5661-5671.2002

De Angelis M, Di Cagno R, Huet C, Crecchio C, Fox PF, Gobbetti M (2004) Heat shock response in Lactobacillus plantarum. Appl Environ Microbiol 70: 1336-1346. doi: 10.1128/AEM.70.3.1336-1346.2004

De Angelis M., Gobbetti M (2011) Stress responses of lactobacilli. In Stress responses of lactic acid bacteria, Papadimitriou K, Tsakalidou E eds, pp 219-249. Springer, New York. doi: 10.1007/978-0-38792771-8

Derré, I, Rapoport G, Msadek T (1999) CtsR, a novel regulator of stress and heat shock response, controls clp and molecular chaperone gene expression in Gram-positive bacteria. Mol Microbiol 31: 117-131. doi: 10.1046/j.1365-2958.1999.01152.x

Derré I, G. Rapoport G, Msadek T (2000). The CtsR regulator of stress response is active as a dimer and specifically degraded in vivo at $37^{\circ} \mathrm{C}$. Mol Microbiol 38: 335-347. doi: 10.1046/j.13652958.2000.02124.x

Derré I, Rapoport G, Devine K, Rose M, Msadek T (1999) ClpE, a novel type of HSP100 ATPase, is part of the CtsR heat shock regulon of Bacillus subtilis. Mol Microbiol 32: 581-593. doi: 10.1046/j.13652958.1999.01374.x

Di Cagno R, Minervini G, Sgarbi E, Lazzi C, Bernini V, Neviani E, Gobbetti M (2010) Comparison of phenotypic (Biolog System) and genotypic (random amplified polymorphic DNA-polymerase chain reaction, RAPD-PCR, and amplified fragment length polymorphism, AFLP) methods for typing Lactobacillus plantarum isolates from raw vegetables and fruits. Int I Food Microbiol 143: 246-253. doi: 10.1016/j.ijfoodmicro.2010.08.018

Drews O, Weiss W, Reil G, Parlar H, Wait R, Görg A (2002) High pressure effects step-wise altered protein expression in Lactobacillus sanfranciscensis. Proteomics 2: 765-774. doi: 10.1002/1615-9861(200206)2:6<765::AID-PROT765>3.0.CO;2-V
Ehrmann MA, Scheyhing CH, Vogel RF (2001) In vitro stability and expression of green fluorescent protein under high pressure conditions. Lett Appl Microbiol 32: 230-234. doi: 10.1046/j.1472765X.2001.00892.x

Fiocco D, Collins M, Muscariello L, Hols P, Kleerebezem M, Msadek T, Spano G (2009) The Lactobacillus plantarum fts $H$ gene is a novel member of the CtsR stress response regulon. I Bacteriol 191: 16881694 doi: 10.1128/JB.01551-08

Fiocco D, Capozzi V, Collins M., Gallone A, Hols P, Guzzo J, Weidmann S, Rieu A, Msadek T, Spano G (2010) Characterization of the CtsR stress response regulon in Lactobacillus plantarum. J Bacteriol 192: 896-900. doi: 10.1128/JB.01122-09

Franz CMAP and Holzapfel WH. (2011) Chapter 1. The Importance of Understanding the Stress Physiology of Lactic Acid Bacteria. In Stress responses of lactic acid bacteria, Papadimitrious K, Tsakalidou E eds, 530: 13-15. Springer Science \& Business Media. doi: 10.1007/978-0-387-92771-8

Garai-Ibabe G, Ibarburu I, Berregi I, Claisse O, Lonvaud-Funel A, Irastorza A, Dueñas MT (2008) Glycerol metabolism and bitterness producing lactic acid bacteria in cidermaking. Int J Food Microbiol 121: 253-261. doi: 10.1016/j.ijfoodmicro..11.004

Gökmen V, Acar J (2004) Fumaric acid: The indicator of microbial spoilage of apple juice. Food Additives and Contaminant 21: 626-631. doi: 10.1080/02652030410001712501

Guidone A, Parente E, Zotta T, Guinane CM, Rea MC, Stanton C, Ross RP, Ricciardi A (2015) Polymorphisms in stress response genes in Lactobacillus plantarum: implications for classification and heat stress response. Ann Microbiology 65: 297-305. doi:10.1007/ s13213-014-0862-7

Hammes W, Hertel C (2009) Genus I. Lactobacillus beijerinck 1901, 212AL. In Bergey's Manual of Systematic Bacteriology, De Vos P, Garrity G, Jones D, Krieg NR, Ludwig W, Rainey FA, Schleifer $\mathrm{KH}$, Whitman WB eds, 2nd edn, pp 465-513. New York, Springer. doi: 10.1007/0-387-28022-7

Hecker M, Schumann W, Volker U (1996) Heat-shock and general stress response in Bacillus subtilis. Mol Microbiol 19: 417-428. doi: 10.1046/j.1365-2958.1996.396932.x

Helmann JD, Wu MF, Kobel PA, Gamo FJ, Wilson M., Morshedi MM, Navre M, Paddon C. (2001) Global transcriptional response of Bacillus subtilis to heat shock. I Bacteriol 183: 7318-7328. doi: 10.1128/JB.183.24.7318-7328.2001

Hörmann S, Scheyhing C, Behr J, Pavlovic M, Ehrmann M, Vogel RF (2006) Comparative proteome approach to characterize the high-pressure stress response of Lactobacillus sanfranciscensis DSM 20451(T). Proteomics 6: 1878-1885. doi: 10.1002/pmic.200402086

Huang CC, Lee FL, Liou JS (2010) Rapid discrimination and classification of the Lactobacillus plantarum group based on a partial dnaK sequence and DNA fingerprinting techniques. Antonie V an Leeuvenboek 97: 289-296. doi: 10.1007/s10482-009-9409-5

Ibarburu I, Aznar R, Elizaquível P, García-Quintás N, Lopés P, Munduate A, Irastorza A, Dueñas M'T (2010) A real time PCR assay for detection and quatification of 2-branched (1,3)-D-glucan producing lactic acid bacteria in cider. Int J Food Microbiol 143: 26-31. doi: 10.1016/j.ijfoodmicro.2010.07.023

Ingmer H, Vogensen FK, Hammer K, Kilstrup M (1999) Disruption and analysis of the $\operatorname{clpB}, \operatorname{clpC}$ and $\mathrm{clpE}$ genes in Lactobacillus lactis: ClpE, a new Clp family in Gram-Positive bacteria. I Bacteriol 181: 2075-2083

Jofré A, Champomier-Vergés M, Anglade P, Baraige F, Martin B, Garriga M, Zagorec M, Aymerich T (2007) Protein synthesis in lactic acid and pathogenic bacteria during recovery from a high pressure treatment. Res Microbiol 158: 512-520. doi:10.1016/j. resmic.2007.05.005

Juvonen R, Virkajärvi V, Priha O, Laitila A (2011) Microbiological spoilage and safety risks in non-beer beverages. VTT Tiedotteita-Research Notes 2599. doi: 10.13140/RG.2.1.3166.8562

Korakli M, Ganzle MG, Knorr R, Frank M, Rossmann A, Vogel RF (2002) Metabolism of Lactobacillus sanfranciscensis under high pressure: investigations using stable carbon isotopes. Trends in High Pressure Bioscience and Biotechnology 19: 287-294. http://dx.doi.org/10.1016/ S0921-0423(02)80114-9

Kruger E, Hecker M (1998) The first gene of the Bacillus subtilis clpC operon, $c t s R$, encodes a negative regulator of its own operon and other class III heat shock genes. I Bacteriol 180: 6681-6688

Lawlor K, Schuman J, Simpson P, Taormina J (2009) In Compendium of the Microbiological Spoilage of Foods and Beverages, Food Microbiology and Safety, Sperber WH, Doyle MP eds, pp 245-283. Springer New York. doi: 10.1007/978-1-4419-0826-1

Lorca G, Font de Valdez G (2009) Lactobacillus stress Responses In Lactobacillus Molecular Biology: From Genomic to Probiotics, Ljung A, Wadström T eds, pp 115-129. Caister Academy Press, Norfolk, UK. doi: 10.1002/elsc.200990012

Mathias SP, Rosenthal A, Gaspar A, Argao GMF, Slongo-Marcusi A (2013) Prediction of acid lactic-bacteria growth in turkey ham processed by high hydrostatic pressure. Brazilian J Microbiol 44: 23-28. doi: 10.1590/S1517-83822013005000014 
Molenaar D, Bringel F, Schuren FH, de Vos WM, Siezen RJ, Kleerebezem M (2005) Exploring Lactobacillus plantarum genome diversity by using microarrays. J Bacteriol 187: 6119-6127. doi: 10.1128/ JB.187.17.6119-6127.2005

Mota MJ, Lopes RP, Delgadillo I, Saraiva JA (2013) Microorganisms under high pressure--adaptation, growth and biotechnological potential. Biotechnol Adv 31: 1426-1434. doi: 10.1016/j.biotechadv.2013.06.007

Parente E, Ciocia F, Ricciardi A, Zotta T, Felis GE, Torriani S (2010) Diversity of stress tolerance in Lactobacillus plantarum, Lactobacillus pentosus and Lactobacillus paraplantarum: a multivariate screening study. Int J Food Microbiol 144: 270-279. doi: 10.1016/j.ijfoodmicro.2010.10.005

Rendueles E, Omer MK, Alvseike O, Alonso-Calleja C, Capita R, Prieto M (2010) Microbiological food safety assessment of high hydrostatic pressure processing: A review. LWT - Food Science and Technology 44: 1251-1260. http://dx.doi.org/10.1016/j.lwt.2010.11.001

Ricciardi A, Parente E, Guidone A, Ianniello RG, Zotta T, Abu Sayem SM, Varcamonti M (2012) Genotypic diversity of stress response in Lactobacillus plantarum, Lactobacillus paraplantalum and Lactobacillus pentosus. Int Food Microbiol 157: 278-285. doi: 10.1016/j.ijfoodmicro.2012.05.018

Russo P, Mohedano ML, Capozzi V, Fernández de Palencia P, López P, Spano G (2012) Comparative proteomic analysis of Lactobacillus plantarum WCFS1 and $\Delta$ ctsR mutant strains under physiological and heat stress conditions. Int J Mol Sci 13: 10680-10696

Salminen S, von Wright A (2004) Lactic acid bacteria. Microbiology and functional aspects. pp 633. Marcel Dekker, New York, USA

Sato T, Kato C, Horikoshi K (1995) The effect of high pressure on gene expression by the lac and tac promoters in Escherichia coli. J Marine Biotechnol 3: 89-92

Sauvageot N, Gouffi K, Laplace J, Auffray Y (2000) Glycerol metabolism in Lactobacillus collinoides: production of 3-hydroxypropionaldehyde, a precursor of acrolein. Int J Food Microbiol 55: 167-170. http://dx.doi.org/10.1016/S0168-1605(00)00191-4

Scheyhing CH, Hörmann S, Ehrmann MA, Vogel RF (2004) Barotolerance is inducible by preincubation under hydrostatic pressure, cold-, osmotic-, and acid-stress conditions in Lactobacillus sanfranciscensis. DSM 2045 20451T. Lett Appl Microbiol 39: 284-289. doi: 10.1111/j.1472-765X.2004.01578.x

Schumann W (2003) The Bacillus subtilis heat shock stimulon. Cell Stress Chaperones 8: 207-217

Serrano LM, Molenaar D, Wels M, Teusink B, Bron PA, de Vos WM, Smid EJ (2007) Thioredoxin reductase is a key factor in the oxidative stress response of Lactobacillus plantarum WCFS1. Microbial Cell Factories 6: 29. doi: 10.1186/1475-2859-6-29

Serrazanetti DI, Gottardi D, Montanari C, Gianotti A (2013) Dynamic stresses of lactic acid bacteria associated to fermentation processes. Lactic Acid Bacteria - Re'D for Food, Health and Livestock Purposes 23: 539-570. http://dx.doi.org/10.5772/51049

Serrazanetti DI, Guerzoni ME, Corsetti A, Vogel RF (2009) Metabolic impact and potential exploitation of the stress reactions in lactobacilli. Food Microbiol 26: 700-711. doi: 10.1016/j.fm.2009.07.007

Shah NP (2007) Functional cultures and health benefits. Int Dairy J 17: 1262-2127. http://dx.doi.org/10.1016/j.idairyj.2007.01.014

Siezen RJ, Tzeneva VA, Castioni A, Wels M, Phan HTK, Rademaker JLW, Starrenburg MJC, Kleerebezem M, Molenaar D, van Hylck- ama Vlieg JET (2010) Phenotypic and genomic diversity of Lactobacillus plantarum strains isolated from various environmental niches. Environ Microbiol 12: 758-773. doi:10.1111/j.1462-2920.2009.02119.x

Siragusa S, De Angelis M, Di Cagno R, Rizzello CG, Coda R, Gobbetti M (2007) Synthesis of $\gamma$-aminobutyric acid by lactic acid bacteria isolated from a variety of Italian cheeses. Appl Environ Microbiol 73: 7283-7290. doi: 10.1128/AEM.01064-07

Smeds A, Varmanen P, Palva A (1998) Molecular characterization of a stress-inducible gene from Lactobacillus belveticus. J Bacteriol 180: 6148-6153

Smits GJ, Brul S (2005) Stress tolerance in fungi - to kill a spoilage yeast. Curr Opin Biotechnol 16: 225-230. doi: 10.1016/j.copbio.2005.02.005

Sokołowska B, Skąpska S, Fonberg-Broczek M, Niezgoda J, Rutkowska M, Chotkiewicz M, Dekowska A, Dobros N, Rzoska SJ (2012) Impact of high hydrostatic pressure on native microflora and colour of root vegetable juices. Post Nauki Technol Przem Rol-Spoż 67: 5-15 (in Polish)

Sokołowska B, Skapska S, Fonberg-Broczek M, Niezgoda J, Rutkowska M, Dobros N, Rzoska JS. (2014) The impact of high hydrostatic pressure (HHP) on native microflora and the colour of beetroot juice - a preliminary shelf-life study. In Industrial, Medical and Environmental Applications of Microorganisms: Current Status and Trends, Mendez-Vilas A, pp 380-384. Wageningen Academic Publisher. doi:10.3920/978-90-8686-795-2

Stortz G, Hengge-Aronis R eds (2000) Bacterial Stress Responses. pp 485. ASM Press, Washington, DC. doi: 10.1128/9781555816841

Ulmer HM, Herberhold H, Fahsel S. (2002) Effects of pressure induced membrane phase transition on HorA inactivation in Lactobacillus plantarum. Appl Environ Microbiol 68: 1088-1095. doi: 10.1128/ AEM.68.3.1088-1095.2002

Van de Guchte M, Serror P, Chervaux Ch, Smokvina T, Ehrlich SD, Maguin E (2002) Stress responses in lactic acid bacteria. Antonie van Leeuwenboek 82: 187-216. doi: 10.1023/A:1020631532202

Varmanen P, Ingmer H, Vogensen FK (2000) ctsR of Lactococcus lactis encodes a negative regulator of clp gene expression. Microbiology 146: 1447-1455. doi: 10.1099/00221287-146-6-1447

Vogel RF, Pavlovic M, Hörmann S, Ehrmann MA (2005) High pressure-sensitive expression in Lactobacillus sanfranciscensis. Brazilian J Med Biol Res 38: 1247-1252. doi: /S0100-879X2005000800013

Welch TJ, Farewell A, Neidhardt FC, Bartlett DH (1993) Stress response of Escherichia coli to elevated hydrostatic pressure. J Bacteriol 175: 7170-7177

Wemekamp-Kamphuis HH, Karatzas AK, Wouters JA (2002) Enhanced levels of cold shock proteins in Listeria monocytogenes LO28 upon exposure to low temperature and high hydrostatic pressure. Appl Environ Microbiol 68: 456-463. doi: 10.1128/AEM.68.2.456463.2002

Wouters PC, Glaasker E, Smelt JPPM (1998) Effects of high pressure on inactivation kinetics and events related to proton efflux in Lactobacillus plantarum. Appl Environ Microbiol 64: 509-514

Zuber U, Schumann W (1994) CIRCE, a novel heat shock element involved in regulation of heat shock operon dnaK of Bacillus subtilis. J Bacteriol 176: 1359-1363. doi: 10.1128/jb.176.5.1359-1363.1994. 